\title{
Financial Indicators of Selected Service-Provider Companies of Telecommunication Sector in India: An Empirical Study
}

\author{
Ajmera Tushar R. ${ }^{1}$ \\ ${ }^{1}$ M. Phil. Research Scholar, Department of Commerce, \\ Saurashtra University, Rajkot, Gujarat - 360005, India
}

\begin{tabular}{|c|c|}
\hline Article Info & Abstract \\
\hline Article history: & Purpose: The aim of this article is to measure profitability of selected services \\
\hline Received: 15 July 2020 & provider companies of telecommunication sector in India. The study also aims \\
\hline Revised: 26 July 2020 & to identify liquidity and solvency of the selected services provider companies \\
\hline d: 19 August 2020 & $\begin{array}{l}\text { of telecommunication, and how these indicators determine their management } \\
\text { efficiency. }\end{array}$ \\
\hline Keyv & Approach/Methodology/Design: In this study, three service-provider \\
\hline Financial Indicators, & telecommunication companies operating in India were selected. The study \\
\hline Profitability, & period is from 2013-14 to 2017-18. The criterion for selection of samples is \\
\hline Liquidity, Solvency, & market capitalization in which higher capitalized companies are selected like \\
\hline $\begin{array}{l}\text { Telecommunication sector, } \\
\text { Market capitalisation }\end{array}$ & $\begin{array}{l}\text { Bharti Airtel, Tata Communication and Reliance Communication. In this } \\
\text { study ratio analysis is used as accounting tool, and One-way Anova technique }\end{array}$ \\
\hline & is used as statistical tool for the identification of difference between the \\
\hline JEL: C30, C40, M41, O16, & sample means. \\
\hline L65, L51, G30. & $\begin{array}{l}\text { Findings: The major findings of the study indicate that Bharti Airtel and Tata } \\
\text { Communication are in a better financial soundness as compared to Reliance }\end{array}$ \\
\hline Paper Type : & Communication. In addition, the results of the study reveal that Reliance \\
\hline & Communication suffered huge losses during the study period. \\
\hline 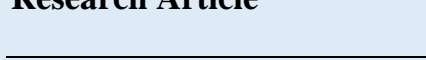 & Practical Implications: The study examines the status of the \\
\hline $\begin{array}{l}\text { Corresponding Author: } \\
\text { Ajmera Tushar R. }\end{array}$ & $\begin{array}{l}\text { telecommunication sector with the current rules and regulations provided by } \\
\text { government. It also assess the financial condition of the selected } \\
\text { telecommunication companies, providing a systematic evaluation based on }\end{array}$ \\
\hline Ema & $\begin{array}{l}\text { certain financial indicators that can help investors make relevant decisions. } \\
\text { Originality/value: The financial indicators are important figures which give }\end{array}$ \\
\hline shar94@gmail.con & $\begin{array}{l}\text { an overview about the financial health of any particular organization. There } \\
\text { are number of financial indicators which are employed to identify the fair and } \\
\text { true picture of organization. Profitability, liquidity and solvency ratios are } \\
\text { one method for the identification of financial strength or weakness out of } \\
\text { number of methods. }\end{array}$ \\
\hline
\end{tabular}

\section{Introduction}

India is currently the world's second largest telecommunications market with a subscriber base of 1.20 billon (Sravanth \& Kannaiah, 2019). The Indian government provides liberal and reformist policies to Indian citizens. The strong customer demand in the country resulted in rapid growth in the Indian telecom sector. The friendly and easy access to telecom equipment and a fair and proactive regulatory framework provided by the government create availability of telecom services to consumer at affordable prices. 
Telecom landscape in India has changed completely since liberalization and monopolies in Telecom sector have been replaced with competitive regime (Gupta, 2002). As per the GSMA report, the telecom industry supports $6.5 \%$ of India's GDP (Telecommunication Annual Report, 2019). The fast commoditization of the telecom service/products had necessitated strong initiatives in the Sales and Distribution network. The result is a better service at competitive prices for the customer.

In general, the telecom sector has undergone a huge change over the years because of the introduction of telecom reformation policy by the Government of India. A new telecom policy was announced in the year 2017 (National Digital Communication Policy---2018) which was designed keeping in mind the needs of modern technology like 5G, Machine to Machine interface, Internet of Things and other features. For introducing these features, to serve the nation better, and to build a strong base for Digital India, the telecom sector has also launched - customer focused and -application driven\| strategies. These in turn will help to amplify the opportunities of telecom-based services (Department of Telecommunication Annual report 2019).

In addition, Foreign Direct Investments (FDI) has played a vital role in shaping the telecom sector in telecom infrastructure and financial expansion over the past years. FDI's during the financial year 2018- 2019 was US\$2.67 million. However, there was a fall in FDI inflow in 2019(Sravanth \& Kannaiah, 2019). The National Digital Communication Policy (NDCP) introduced in 2018 also fulfils the communication and information needs of enterprises and citizens. This policy establishes resilient, secure, ubiquitous and affordable digital communications services and infrastructure. It facilitates digitally empowered society and economy. The main goal of the policy will be achieved by 2022. It will provide broadband for all, create additional 4 million jobs in the Digital Communications Sector and increase the contribution of digital communications sector by 8\%, towards Indian's Gross Domestic Product (Telecommunication annual report, 2019).

Innovation was the key factor for the revenues of the telecom industry in the western countries. Today, however, new wireless applications, low-cost manufacturing innovations, and handset design are some of the areas in which the Asian countries are out-investing the United States and are seen resulting bottom-line impacts to their economies (National Research Council, 2006). In emerging markets, factors such as customer service, regulations and policies are some of the main factors that are shaping the industry (Venkatram, \& Zhu, 2012).

In the Indian context, performance of operators contributes to the growth of the telecommunication industry. The competition between companies serves the customer by getting affordable plans and better services. Moreover, market liberalization is a determining factor in the success of the Indian telecommunication sector. It creates a competitive market where every company has to excel and provide the best services and tariffs. More importantly, the commitment of the Indian government to offer friendly-policy and flexible regulation to emerging issues contributed greatly to the expansion of the telecommunication sector. 
The Indian government recognizes the significance of this sector. Telecommunications has been and will continue to be an important foundation for innovative new industries that use telecommunications as a primary technological enabler and foundation (National Research Council, 2006). That being said, one should know that "not everything that glitters is gold". For example, the emerging markets face lacking of talented resources and intense competition in order to sustain the growth that has been observed over the past few years (Ken, 2007).

The present study is an attempt to examine status of the telecommunication sector with the current rules and regulations provided by government. The aim is also to assess the financial condition of telecommunication sector. For this purpose, the researcher selected certain financial indicators for the analysis and interpretation of the financial performance of telecommunication sector. For the identification of financial performance, the basic criteria are awareness about profitability, liquidity and how the companies utilise their assets in concern with profit maximization and wealth maximisation.

\section{Literature Review}

The financial indicators are very important figures which give an idea about financial health of any particular organisation. There are number of financial indicators which are employed to identify the fair and true picture of organisation. For instance, profitability, liquidity and solvency ratios are methods for identification of financial strength or weakness of companies. This literature review presents an evaluation of the relevant studies.

Sanjay Pandey (2013) has carried out a study to measure the financial soundness of Indian telecom companies. In this study, Pandey indentified that telecom industry of India underwent a high pace of market liberalization and growth since 1990s and now it is considered as world's most competitive and one of the fastest growing telecom markets ( Pandey, 2013). The firm's operating performance has been dependent on specific key financial factors like turnover, profit, asset utilization etc and ratios are found in statement of profit and loss and balance sheet that is direct and indirectly connected. The major finding of the study was that the selected telecom companies were performing as the most dynamic sector in Indian economy and their respective impact is well-recognized by the government.

Sumaira (2016) has analysed the financial statements of Idea Cellular and Reliance Telecommunication. This study assessed the competitive position of Idea Cellular and Reliance Telecom Company on the basis of financial statements which are issued on a yearly basis. Financial statements provide all answers which are asked or raised by creditors and investors. This study emphasised on the measurement of selected financial health of firms.

Yadav (2017) has analysed performance measurement system in telecommunication services. It conducted to analyze the performance of selected Indian companies. In this study, researcher indentified that the fast changing technology leads to increased competition with the consumer usages in telecommunication services. The telecommunication services provider companies are 
shifting their strategy from customer to latest technology. The main question of telecom companies is not only continuing in the field, but also to compete in the market.

Tasneem Khan (2018) has studied on a panel data analysis the profitability determinants of Indian telecom companies. In this study, researcher analysed the financial health of companies belonging to Indian telecom industry. In this study, the balance panel dataset method was used for the identification of profitability of Indian telecom sector companies which are registered on NSE (National Stock Exchange) during the time span of 2004-2017. The major finding of the study indicated that the size and growth of a company have direct significant relationship with profitability, whereas leverage has a negative relationship and liquidity and z-score has insignificant impact on profitability.

\section{Methodology and Procedures}

The method employed for analyzing data include Net profit margin ratio and return on capital. For Data collection, annual reports of selected companies are used. In addition, relevant websites and financial statements are also considered. These data also known as secondary data sources are the sources for this study. The time span of the study is from 2013-14 to 2017-18.

The functional scope of the study is to identify the profitability with employing Net profit margin ratio and then liquidity with the help of current ratio and quick ratio. In addition, management efficiency with ratio of fixed assets turnover and total assets turnover ratio are employed in the study. For this study, the selected companies provided their services in India so, whole India is considered as geographical scope.

Table 1: Selection of Sample

\begin{tabular}{|l|l|}
\hline Target Population & $\begin{array}{l}\text { Whole Telecommunication services provider companies which are } \\
\text { listed on stock exchange. }\end{array}$ \\
\hline Sampling Method & $\begin{array}{l}\text { Non-Probability technique Should Be Considered And In Which } \\
\text { Judgmental And Stratified Sampling method used. }\end{array}$ \\
\hline Sample Size & $\begin{array}{l}\text { Total Sample Should Be Considered As Three services provider } \\
\text { companies based On Higher Market Capitalisation. }\end{array}$ \\
\hline Selection of sample & $\begin{array}{l}\text { 1. Bharti Airtel } \\
\text { 2. Tata Communication } \\
\text { 3. Reliance Communication. }\end{array}$ \\
\hline
\end{tabular}

\section{Results and Discussion}


The data analysis is presented in three headings. The first part of the analysis is concerned with profitability ratios, while the second part of analysis presents the results of liquidity ratios. The third part presents the data the analysis of management efficiency ratios.

Table No. 2: Profitability Ratios

\begin{tabular}{|c|c|c|c|c|c|c|}
\hline & \multicolumn{3}{|l|}{ Net Profit Margin Ratio } & \multicolumn{3}{c|}{ Return on Capital Employed } \\
\hline YEAR & $\begin{array}{c}\text { BHARTI } \\
\text { AIRTEL }\end{array}$ & $\begin{array}{c}\text { TATA } \\
\text { COMM }\end{array}$ & $\begin{array}{c}\text { RELIANCE } \\
\text { COMM }\end{array}$ & $\begin{array}{c}\text { BHARTI } \\
\text { AIRTEL }\end{array}$ & $\begin{array}{c}\text { TATA } \\
\text { COMM }\end{array}$ & $\begin{array}{c}\text { RELIANCE } \\
\text { COMM }\end{array}$ \\
\hline $2013-14$ & 13.22 & 12.39 & 6.53 & 13.18 & 8.85 & 1.68 \\
\hline $2014-15$ & 23.78 & 15.61 & -1.42 & 17.32 & 11.03 & 0.08 \\
\hline $2015-16$ & 12.9 & 8.19 & -3.79 & 8.38 & 6.87 & 0.76 \\
\hline $2016-17$ & -15.93 & 13.61 & -50.77 & 7.23 & 4.12 & 0.25 \\
\hline $2017-18$ & 0.14 & 5.2 & -442.4 & 2.96 & 8.19 & 0.17 \\
\hline
\end{tabular}

Source: Annual reports from selected companies

Table No. 1 indicates net profit margin ratio and return on capital employed ratio as profitability ratio for the selected telecommunication companies. In the year 2013-14, net profit margin ratio was $13.22 \%$ and it increased up to $23.78 \%$ in the year 2014-15. From 2015-16 to 2017-18, a negative trend is indicated like $12.9 \%,-15.93 \%$ and $0.14 \%$ respectively. Tata communication indicated fluctuating trend during the period in which higher ratio was $15.61 \%$ and lower ratio was 5.2\% in the year 2014-15 and 2017-18 respectively. Reliance communications reveals huge losses during the study period which was $-442.4 \%$ in the year 2017-18. In concern with return on capital employed, Bharti Airtel indicated decreasing trend. In the year 2014-15, the ratio was $17.32 \%$ which is highest ratio and in the year $2017-18$ ratio was $0.17 \%$ which is the lowest ratio during study for Bharti Airtel and Reliance Communication respectively. Tata communication reveals fluctuating trend during the study period and Reliance communication indicated lower return on capital employed ratio from 2013-14 to 2017-18.

Table No. 3: Liquidity Ratios

\begin{tabular}{|c|c|c|c|c|c|c|}
\hline & \multicolumn{5}{|c|}{ Current Ratio } & Quick Ratio \\
\hline Year & $\begin{array}{c}\text { Bharti } \\
\text { Airtel }\end{array}$ & $\begin{array}{c}\text { Tata } \\
\text { Comm }\end{array}$ & $\begin{array}{c}\text { Reliance } \\
\text { Comm }\end{array}$ & Year & $\begin{array}{c}\text { Bharti } \\
\text { Airtel }\end{array}$ & $\begin{array}{c}\text { Tata } \\
\text { Comm }\end{array}$ \\
\hline $2013-14$ & 0.93 & 1.33 & 0.72 & $2013-14$ & 0.93 & 1.33 \\
\hline $2014-15$ & 0.73 & 0.99 & 1.48 & $2014-15$ & 0.73 & 0.99 \\
\hline
\end{tabular}




\begin{tabular}{|l|l|l|l|l|l|l|}
\hline $2015-16$ & 0.61 & 1.06 & 0.75 & $2015-16$ & 0.61 & 1.06 \\
\hline $2016-17$ & 0.49 & 0.88 & 0.57 & $2016-17$ & 0.49 & 0.88 \\
\hline $2017-18$ & 0.49 & 1.06 & 0.64 & $2017-18$ & 0.49 & 1.06 \\
\hline
\end{tabular}

Source: Annual reports from selected companies

Table No. 2 indicated liquidity ratios of selected companies form 2013-14 to 2018-19. The ideal current ratio is 2:1. In Bharti Airtel, current ratio is $0.93: 1,0.73: 1,0.61: 1$ and $0.49: 1,0.49: 1$ respectively during the study period 2013-14 to 2017-18. In Tata Communication, there is fluctuating way of current ratio during the study period; that is, $1.33: 1,0.99: 1,1.06: 1,0.88: 1$, 1.06:1, respectively. In the year 2013-14 to 2017-18 and in the year 2013-14, the table above shows the highest current ratio and in the year 2016-17 shows the lowest current ratio 1.33:1, 0.88:1 respectively. Reliance Communication in the years 2013-14 to 2017-18 shows current ratio at $0.72: 1,1.48: 1,0.75: 1,0.57: 1,0.64: 1$ respectively. During the study period, the ratio $1.48: 1$ is the highest in the year 2014-15, and 0.57:1 is the lowest ratio in the year 2016-17. In Bharti Airtel in the year 2013-14, the quick ratio shows 0.98:1 that is higher in the study period and 0.75:1, $0.55: 1,0.78: 1,0.74: 1$, in the year $2014-15$ to $2017-18$ respectively. In connection with Tata Communication during study period, the company meets the prescribed standards. In the year 2013-14, it yields the highest ratio which was 1.45:1 and the lowest ratio was 1.01:1. This indicates the effective management of quick assets and liabilities. For Reliance Communication, quick ratio in the year 2013-14 is 1.23:1 and it increases to 1.61:1 in the year 2014-15. However, it decreases in the year 2015-16 to $0.88: 1$ and further decrease to $0.81: 1$ in the year 2016-17. Finally, Tata communication indicated better performance of current ratio and quick ratio during the study period.

Table No. 4: Management Efficiency Ratios

\begin{tabular}{|c|c|c|c|c|c|c|}
\hline & \multicolumn{3}{|c|}{ Fixed Assets Turnover Ratio } & \multicolumn{2}{l|}{ Total Assets Turnover Ratio } \\
\hline YEAR & $\begin{array}{c}\text { BHARTI } \\
\text { AIRTEL }\end{array}$ & $\begin{array}{c}\text { TATA } \\
\text { COMM }\end{array}$ & $\begin{array}{c}\text { RELIANCE } \\
\text { COMM }\end{array}$ & $\begin{array}{c}\text { BHARTI } \\
\text { AIRTEL }\end{array}$ & $\begin{array}{c}\text { TATA } \\
\text { COMM }\end{array}$ & $\begin{array}{c}\text { RELIANCE } \\
\text { COMM }\end{array}$ \\
\hline $2013-14$ & 0.86 & 0.49 & 0.37 & 0.84 & 0.5 & 0.25 \\
\hline $2014-15$ & 0.85 & 0.45 & 0.34 & 0.78 & 0.5 & 0.23 \\
\hline $2015-16$ & 0.79 & 0.52 & 0.40 & 0.65 & 0.52 & 0.23 \\
\hline $2016-17$ & 0.69 & 0.51 & 0.13 & 0.71 & 0.53 & 0.1 \\
\hline $2017-18$ & 0.51 & 0.48 & 0.42 & 0.57 & 0.57 & 0.06 \\
\hline
\end{tabular}

Source: annual reports from selected companies

Table No. 3 indicated fixed assets turnover ratio and total assets turnover ratio as management efficiency ratio. Bharti Airtel indicated ratio in decreasing way, for the year 2013-14 the ratio is $0.86: 1$ and slickly decrease by $0.1: 1$ and stand at $085: 1$ in the year 2014-15 in the year 2015-16

ISSN: $2708-9320$ (Print)

Copyright (C) 2020, Journal of Advanced Research in Economics and Administrative Sciences (JAREAS), Under the license CC BY 4.0 
the ratio is $0.79: 1$ and decrease to $0.69: 1$ in the year 2016-17. In the year2017-18 ratio stood at 051:1 its compare to 2013-14 the ratio is decrease by $0.35: 1$ during the study period. Tata communication shows fixed assets turnover ratio in the year 2013-14 as 0.49:1 and decrease to $0.45: 1$ but next year 2015-16 it is increase to $0.52: 1$. In the year 2016-17 ratio shows 051:1 and decrease to $048: 1$ in the year 2017-18. Reliance communication indicated fluctuating tend during the study period in concern with fixed assets turnover ratio. From 2013-14 to 2017-18 fixed assets turnover ratio indicated approx constant trend except the year 2016-17. In concern with Total assets turnover ratio for the year 2013-14 to 2017-18, BhartiAirtel shows decreasing trend except the year 2016-17. In the year 2013-14 the ratio is $0.84: 1$ and decrease to $0.78: 1$ and next year 2015-16 it is at $0.65: 1$ and increase to $0.71: 1$ in the year 2016-17 but major decrease in the year 2017-16 that is $0.71: 1$ to $0.57: 1$ the overall decrease by $0.14: 1$. Tata Communication shows increasing trend of total assets turnover ratio in which the year 2013-14 to 2017-18. The ratio is $0.50: 1,0.50: 1,0.52: 1,0.53: 1$ and $0.57: 1$ respectively that also indicates good condition for the company. Reliance communication indicated decreasing trend during study period. In the year 2013-14 the ratio was $0.18: 1$ and minor decrease to $0.17: 1$ in the year 2014-15 and also same in the next year but highly decrease in the year of 2016-17 and stood at just only 0.07:1.

\section{One Way Anova for Hypothesis Testing:}

$\mathbf{H}_{\mathbf{0}}=$ There is no significant difference between profitability, liquidity and management efficiency ratios among selected companies.

$\mathbf{H}_{1}=$ There is no significant difference between profitability, liquidity and management efficiency ratios among selected companies.

Table 5: ANOVA Test

\begin{tabular}{|l|l|c|c|c|}
\hline $\begin{array}{l}\text { Sr. } \\
\text { No. }\end{array}$ & Financial Indicators & Cal. Value & Table Value & $\begin{array}{l}\text { Accepted or Rejected } \\
\mathrm{H}_{0}\end{array}$ \\
\hline 1. & Net profit margin & 1.5264 & 3.8852 & Accepted \\
\hline 2. & Return of capital employed & 9.3434 & 3.8852 & Rejected \\
\hline 3. & Current ratio & 3.2602 & 3.8852 & Accepted \\
\hline 4. & Quick ratio & 4.6612 & 3.8852 & Rejected \\
\hline 5. & Fixed Assets Turnover Ra. & 17.8721 & 3.8852 & Rejected \\
\hline 6 & Total Assets Turnover Ra. & 56.3663 & 3.8852 & Rejected \\
\hline
\end{tabular}

Source: Author

The table above presents the one-way Anova test results for the identification of difference between selected ratios. It is performed at 5\% level of significance. Net profit margin ratio indicated fail to reject null hypothesis or it can be said that there is no statistical evidence which can reject null hypothesis. It means the performance of all selected companies in concern with net 
profit margin was similar. The other ratios indicate that there is a significant difference between selected ratios during the study period.

\section{Conclusion and Suggestion}

With reference to Return on capital employed, except for Tata Communication, Bharti Airtel and Reliance Communication companies show decreasing trend. Reliance shows very low ratios during the study period. The highest capital employed is $17.32 \%$ in the year 2014-15 and the lowest is $0.08 \%$ in the year 2014-15 of Bharti Airtel and Reliance Communication respectively. The standard current ratio is $2: 1$ and in this study no single company is satisfied with standard current ratio during the study period. The highest current ratio is 1.33:1 in the year 2013-14 of Tata communication and the lowest ratio is 0.49:1 in the year 2017-18 of Bharti Airtel. Therefore, it is found out that the overall current assets are less than the current liabilities.

With reference to total assets turnover ratio, the highest ratio is $0.84: 1$ in the year 2013-14 of Bharti Airtel and the lowest ratio is $0.06: 1$ in the year 2017-18 of Reliance communication. With regard to Bharti Airtel, the total assets turnover ratio is in a decreasing trend except the year 201617. Tata communication's performance in relation to this ratio is good compared to the other companies. In the year 2017-18, the ratio of Reliance Communication is 0.06:1, reflecting poor performance of sales or total assets management.

\section{Conflict of Interest}

The author of the article declares no conflict of interest.

\section{Funding}

This research study was not funded by any institution. The author conducted the study on his own expenses.

\section{References}

Gupta, R. (2002). Telecommunications liberalisation: critical role of legal and regulatory regime. Economic and Political Weekly, 1668-1675.

Ken, W. (2007). Asia's high Telecom growth threatened, Telecommunications, Telecom Magazine, Horizon House.

Khan, M. M., \& SAFIUDDIN, D. S. K. (2016). Liquidity and Profitability Performance Analysis of Selected Telecoms Companies. International Journal of Research in Regional Studies, Law, Social Sciences, Journalism and Management Practices (AIJRRLSJM), 1(8), 365376.

Khan, T. (2018). Panel Data Analysis of profitability determinants: evidence from Indian telecom companies . Scientific Research an academic publisher, 3581-3591.

National Research Council, (2006). The Importance of Telecommunications and 
Telecommunications Research, Renewing U.S. Telecommunications Research, Washington, DC: The National Academies Press.

Sumaira, J., (2016). Financial statements analysis of Idea Cellular and Reliance Telecommunications: a comparative study . Imperial journal of interdisciplinary research , 1-8.

Sanjay Pandey, V. V. (2013). Measuring Financial Soundness of Indian Telecom Companies- A comparative analysis. The International Journal of management , 1-13.

Sravanth, K. R. S., Sundaram, N., \& Kannaiah, D. (2019). PEST Analysis of Present Indian Telecom Sector. International Journal of Innovative Technology and Exploring Engineering, 9, 4938-4942.

Venkatram, R., \& Zhu, X. (2012). An analysis of factors influencing the telecommunication industry growth: A case study of China and India.

Yadav, V. K. (2017). Performance Measurement system in telecommunication services: a study of selected Indian Companies . International journal of productivity management and assessment technologies , 1-14. 